A. Klimczuk, M. Bieńkowska, Trans Theorizing, [in:] N. Naples, A. Wong, M. Wickramasinghe, R.C. Hoogland (eds.), The Wiley-Blackwell Encyclopedia of Gender and Sexuality Studies, Wiley-

Blackwell, Hoboken, New Jersey 2016, pp. 1-3 http://dx.doi.org/10.1002/9781118663219.wbegss517.

\title{
Trans Theorizing
}

ANDRZEJ KLIMCZUK

Warsaw School of Economics, Poland

\section{MAŁGORZATA BIEŃKOWSKA}

University of Białystok, Poland

"Trans" is an umbrella term encompassing all of the gender practices and identities that fall outside of the binary gender system. Trans theorizing is the formation of a system of ideas used to explain the nature of gender and gender identity in understanding the lived experiences of trans people. In the beginning, trans theories were mainly medical concepts developed in the 1950s and 1960s and psychiatric theories in the 1970s. Later, the medical approach was criticized by scholars and others, including trans people, who challenged the way in which it pathologized trans and gender-nonconforming people. These criticisms opened the way for constructionist theories, which led to the development of the performative perspective and queer theory in the 1990s. The physical embodiment in gender identity is integrated with socially constructed aspects of selfhood in contemporary trans theories. Incorporating, this approach with the, lived experiences of trans people, contemporary trans theorizing reconciles feminist and queer theoretical scholarship with activism and advocacy for trans people and to larger issues of group identity and social oppression (Nagoshi and Brzuzy 2010).

\section{MEDICAL AND PSYCHIATRIC THEORIES}

The concept of "transsexualism" was popularized in the 1950s by Harry Benjamin, an endocrinologist (Stryker 2006). In the 1960s, the scientific approach to this issue was dominated by a medical perspective. It affected the way in which trans people were described and analyzed in the social sciences. Medical discourse mentions "being trapped in the wrong body" and the necessity of sex reassignment surgery to change one's body to match one's gender identity. Benjamin created the classification of "transsexualism" and determined standards of medical care for transsexual people. Doctors considered it to be a medical disorder that can be treated by surgical procedures to allow trans people to embody their "authentic" sex rather than the physical sex in which they were born. The emphasis on authenticity meant that trans people were forced to attempt to "pass" as the "opposite" sex (and to be heterosexual) in order to be considered authentically transsexual and to be eligible for medical intervention. In the 1970s, this focus on authenticity was intensified by psychiatrists who insisted that surgical procedures 
A. Klimczuk, M. Bieńkowska, Trans Theorizing, [in:] N. Naples, A. Wong, M. Wickramasinghe, R.C. Hoogland (eds.), The Wiley-Blackwell Encyclopedia of Gender and Sexuality Studies, Wiley-

Blackwell, Hoboken, New Jersey 2016, pp. 1-3 http://dx.doi.org/10.1002/9781118663219.wbegss517.

were an appropriate method to adjust to the "real sex" with which a transsexual person identified (Hines 2010).

The American Psychiatric Association (APA) adopted the term "transsexual" in the Diagnostic and Statistical Manual (DMS-III) in 1980. The term was replaced in 1987 in the $D S M-I V$ by "gender identity disorder" (GID) to assist in the diagnosis of individuals whose assigned gender at birth diverged from their self-identity and who experienced distress as a result. In 2013, the APA removed GID and replaced it with "gender dysphoria" in the DSM-5 to reflect a new understanding of the diverse ways the people experience and perform gender outside social expectations.

\section{PERFORMATIVITY AND CONSTRUCTIONIST THEORIES OF TRANSSEXUALITY}

When trans people began telling their own stories rather than being spoken about by the medical community, the limitations of medical and psychiatric trans theories became clear. During the 1960s, the first autobiographies of transsexual people began to be published. In 1974 Jan Morris wrote Conundrum, in which she described her own path toward sex reassignment surgery. Since then, many transsexual people have published autobiographies and memoirs describing their experiences of the transition process. They became the main source from which to analyze transsexual people from perspectives other than medical and psychiatric theories.

In the late 1960s, sociologists began to explore the social construction and performative aspects of gender (Hirn 2002). In 1967, sociologist Harold Garfinkel - who developed the perspective of ethnomethodology - detailed the proactive ways in which Agnes, a transgender person, convinced a team of doctors to support her request for gender transition. In Changing Sex: Transsexualism, Technology, and the Idea of Gender (1995), Bernice L. Hausman furthered the constructionist perspective by analyzing the social assumptions of medical discourse on trans people (see also Prosser 1998). Social construction theories demonstrate how the lived experiences of trans people can expose the day-to-day construction of gender in nuanced ways that reveal how gender is socially constructed by all of us in our daily lives (Kessler and McKenna 2000).

Judith Butler (1990) is credited as having developed the theory of gender performativity in which gender is understood as what someone does, rather than what someone is. This idea of gender as performative was the springboard for queer trans theories in that she argues against the distinction between sex and gender and for the power of discourse to construct what we take as natural or normal. In her now-classic book Gender Trouble (1990), Butler explains that 
A. Klimczuk, M. Bieńkowska, Trans Theorizing, [in:] N. Naples, A. Wong, M. Wickramasinghe, R.C. Hoogland (eds.), The Wiley-Blackwell Encyclopedia of Gender and Sexuality Studies, Wiley-

Blackwell, Hoboken, New Jersey 2016, pp. 1-3 http://dx.doi.org/10.1002/9781118663219.wbegss517.

"Gender is the repeated stylization of the body, a set of repeated acts within a highly rigid regulatory frame that congeal over time to produce the appearance of substance, of a natural sort of being" (p. 45). Butler addresses some of the criticism that her book garnered, including lack of attention to transgender and intersexuality, in the introduction to the 1999 edition of the book (Salih 2002). She also takes on other questions that her Gender Trouble evokes in Bodies That Matter (1993). Here she discusses the regulatory production of race and explores how "race" is "lived in the modality of sexuality" and how gender is "lived in the modality of race" (p. 117) to offer a more intersectional understanding of performativity.

\section{TOWARD QUEER THEORY}

In the 1990s, the concept of transgender was introduced as a replacement for the term "transsexual" in order to diminish the primacy of medical discourse. Transgender is the less clinical umbrella term under which transsexual, genderqueer, and other trans identities are covered. Purely medical perceptions of transgender were further undermined by the queer theory that developed at the time and deconstructed the idea of biological sex being entirely natural. For example, Queer Theory/Sociology (1996), edited by Steven Seidman, reflected on the changes in scientific discourse concerning sexuality, sex, sexual orientation, and demonstrates how gender is historically and socially constructed. Seidman and other authors in the volume challenged the knowledge concerning sexual minorities from earlier "naive modernist assumptions."

Queer trans theory contests rigid boundaries and the presumed stable or fixed nature of gender. It views gender and sexuality as always implicated in relations of power that are woven throughout everyday life, discourse, and culture. In this way, it is itself a shifting intellectual and activist project.

SEE ALSO: Essentialism; Genderqueer; Social Identity; Social Role Theory of Sex Differences; Transsexuality; Transvestitism; Queer Theory

\section{REFERENCES}

Bornstein, Kate. 1994. Gender Outlaw. New York: Routledge.

Butler, Judith. 1990; (Anniversary edition 1999). Gender Trouble: Feminism and the Subversion of Identity. New York: Routledge.

Butler, Judith. 1993. Bodies That Matter: On the Discursive Limits of 'Sex'. New York: 
A. Klimczuk, M. Bieńkowska, Trans Theorizing, [in:] N. Naples, A. Wong, M. Wickramasinghe, R.C. Hoogland (eds.), The Wiley-Blackwell Encyclopedia of Gender and Sexuality Studies, Wiley-

Blackwell, Hoboken, New Jersey 2016, pp. 1-3 http://dx.doi.org/10.1002/9781118663219.wbegss517.

Routledge.

Ekins, Richard, and Dave King. 1999. "Towards a Sociology of Transgendered Bodies.” The Sociological Review, 47(3): 580-602.

Garfinkel, Harold. 1967. Studies in Ethnomethodology. Englewood Cliffs NJ: Prentice Hall.

Hausman, Bernice L. 1995. Changing Sex: Transsexualism, Technology, and the Idea of Gender. Durham, NC: Duke University Press.

Hines, Sally. 2010. “Introduction.” In Transgender Identities: Towards a Social Analysis of Gender Diversity, edited by Sally Hines and Tam Sanger, 1-22. New York: Routledge.

Kessler, Suzanne J., and Wendy McKenna. 2000. "Gender Construction in Everyday Life: Transsexualism (Abridged)." Feminism \& Psychology, 10(1):11-29.

Nagoshi, Julie L. and Stephanie Brzuzy. 2010. "Transgender Theory: Embodying Research and Practice." Affilia, 25(4): 431 -443.

Prosser, Jay. 1998. Second Skin: The Body Narratives of Transsexuality. New York: Columbia University Press.

Salih, Sara. 2002. Judith Butler. New York: Routledge.

Seidman, Steven, ed. 1996. Queer Theory/Sociology. Cambridge, MA: Blackwell.

Stryker, Susan. 2006. “(De)Subjugated Knowledges: An Introduction to Transgender Studies.” In The Transgender Studies Reader, edited by Susan Stryker and Stephen Whittle, 1 -17. London: Routledge.

\section{FURTHER READING}

Bieńkowska, Małgorzata. 2012. Transseksualizm w Polsce: Wymiar indywidualny i społeczny przekraczania binarnego systemu płci [Transsexualism in Poland: Individual and Social Dimension Crossing Binary Gender System]. Białystok, Poland: Wydawnictwo Uniwersytetu w Białymstoku.

Hausman, Bernice L. 2001. “Recent Transgender Theory.” Feminist Studies,27(2):465-491. Hines, Sally. 2007. TransForming Gender: Transgender Practices of Identity, Intimacy and Care. Bristol: Policy Press.

Hird, Myra J. 2002. “For a Sociology of Transsexualism.” Sociology, 36(3): 577-595. 